\title{
Enjoy Your Lessons with Fruitful Speaking Activities
}

\author{
Abdullaeva Dilsuz Nuriddinovna \\ An English Teacher of the Specialized, \\ Boarding-School of the Ministry of Internal Affairs
}

\begin{abstract}
How teachers can make their lessons effective by different speaking activities and give students a chance for speaking without fear. There are two main reasons for getting students to speak during a lesson. Giving students practice of language items (vocabulary, grammar functions etc.) - a language practice aim, and developing student's ability to speak fluently and interactively - a speaking fluency aim. In this article it will be presented some great speaking fluency activities which turn to be quite successful for any lesson. The learning outcome is for students to gain confidence in speaking English.
\end{abstract}

Key words: speaking activities, fluency, interactive, language barrier, speaking skills, interview, conversation

Why are your students studying English? Would you agree that most students want to improve their speaking skills, overcome the language barrier and speak fluently? Fluency, which is defined as "being able to speak and write quickly or easily in a given language", helps learners to feel confident while having a conversation in the target language. So each teacher must think of a range of techniques and strategies which will equip students with the possibility to improve their fluency. Each lesson must include an activity to practice speaking for fluency. Here are some beneficial methods for improving speaking skills during English classes:

\section{Questions to a Partner}

Make a list of questions for student A and a list of different questions for student B. They ask each other these questions and they get to answer and respond to. Why is this the best possible activity? Because it maximizes student talking time and I feel this is the best way to engage all the learners in class.

Survey This is a famous activity. Make a list of questions. Students then walk around the class and ask one question to a different person each time. Students love this activity because it allows them to walk around the class and actually talk to some of their friends.

Speed Dating Make a list of questions and students sit down with a partner for a minute or two. When their time is up you ring a bell and they switch partners. What makes this different from a survey is that it's not only one question that they have to ask, it is a few questions. That gives them the opportunity to practice these questions and improve their fluency whenever they have to repeat an answer. Students can also choose which questions they ask their partners. At a more advanced level you can encourage students to ask follow-up questions so that they practice a more natural way of speaking.

Running Sentences English learners have to continue the sentence or an idea or story. One student will start with a story and then stop. After that student the next student has to continue and the next and next... This can also be used in writing where someone writes the beginning of a story, another finally the end. It is also great for conditionals: If one student says "If I had a million dollars I would 
be happy" and then another student continues "If I was happy I would live in a big mansion." Third student "If I lived in a big mansion I would have a butler" and so on.

Deserted Island Asked students to draw a picture of something, anything. Once they have finished tell them that they are on a deserted island and only half of them can survive. They have to try and persuade their friends to pick them. Give them some time to prepare by writing reasons why they should get picked to survive and then once it is their turn they should plead their case for survival. Students really like this. Get them to draw something that helps them imagine it and then also because they are actually fighting for their lives.

Taboo Game Give students a word, let's say politics and then they should try and explain that word to the other students without using similar words. You can put it on a projector or you can put it on the screen. Show them a word and say okay listen you cannot use these words. I prefer using cards and I have got a whole stack of cards that I use. I think it is an easy way to put students into groups what you want to do with most activities is you want to scaffold it. What I do is first is I start off and I say "Okay everyone, explain this word to your friends. You can use these extra words underneath to help you explain. Then, sometime late I say "Okay stop! This is way too easy for you. Let's make it a little bit more difficult. I want you to explain the word without using the words below". Why do we scaffold activities? It is like playing a video game: First when you start playing the game you are going to play it on easy. Then you are going to move on to normal and then to hard. That is the way for students too. With most of our activities we want to make it easy for them to understand at the start. From there you can add rules or extra material to increase the difficulty. A lot of inexperienced teachers start at the most difficult level without considering their student's needs or abilities.

Two Truths, One Lie This is a fun activity. You ask students to write down two things about themselves that are true and then one that is false. Tell them to make it interesting, do not make it anything boring. For example, when you show students how to do it you can say I have three brothers, I cannot eat seafood and my favorite color is red. Then the class should ask you questions to find out which one is the lie. Tell students not to use your examples otherwise you will find that the whole class uses "I have a brother" as one of their statements. They should try and create their own original ideas.

Split them up into groups so that they can practice with their friends. The reason we split learners into groups is to maximize learner talking time. If you use the whole class then students get bored. It takes too long they do not really get a chance to do anything and when students are like that they are then going to zone out. So you want to engage your students as much as possible by making them part of the activity. When they are in their groups tell the students to remember to ask each other extra questions to try and find out which one is the lie. If I said I had three brothers they can ask me: What are their names? How old are they? ,etc.

Alibi This is a really fun activity. Tell the students that yesterday a crime was committed and they want to find a group of students who is responsible. If you have a class of twenty students you could make groups of four. Then an investigator for each one. The investigators teachers should usually make the brightest students so that they can start and ask good questions.

Give the group's a few minutes to create an alibi a story and it is details: Where were they? What were they doing? At what time? What were they eating? What was the weather like? Once they are done each of the four investigators will interview the group and ask them questions. They can give that group of score how much do they believe them. To make it easier you can also write some example questions on the board that the investigators can ask and they can also come up with their own questions. They will interview each group and then after a few minutes move around so that they interview all the groups. Afterwards all the detectives should say which group do they think is 
responsible. This is a great activity! Students like this game and without knowing it they are practicing their English skills and they do love.

Hot Seat With hot seat put the students into groups maybe if you have a group of four students. One student leaves the class, then you tell the other three students a word or phrase. They have to explain to explain it to him or her. What you can do is you can make it more competitive. If you can put the group's against each other and give them a list of words they have to run through, then you will see who finishes first. It can get a little bit loud but if you set the ground rules then it should be a lot of fun.

Twenty Questions We all know this you think of something and the students can ask you to any question to figure out what it is. Is it alive? Is it big? You can ask any question you would like. Once again place the students into groups to make sure that everybody gets a chance.

\section{Zombie Game}

It is called secret zombie. Before class you can have a couple of small strips of paper you write on a $\mathrm{H}$ for human or $\mathrm{Z}$ for a zombie. Let's say if you have a group of twenty students you can make three zombies. The students have to go and have a conversation with another student. They will walk around and have a normal conversation. What did you do last weekend? What's your favorite food? You can give them some sample questions. The thing is while they are talking the zombie should secretly wink at the other students. When they do that person is a zombie. After that conversation ends they should find someone else to talk to and infect them as well. Do this for 4 or 5 conversations then you say stop. All the zombies raise their hands to reveal themselves and the rest of the students see who remained uninfected.

Language, in other words, is how we think. It is how we process information and remember. It is our operating system. Vygotsky (1962) suggested that thinking develops into words in a number of phrases, moving from imaging to inner speech to inner speaking to speech. Tracing this idea backward, speech - talk- is the representation thinking. As such, it seems reasonable to suggest that classrooms should be filled with talk, given that we want them filled with thinking.

References:

1. Celce-Murcia.M. (2001)/Teaching English as a Second or Foreign Language ( ${ }^{\text {rd }}$ ed). USA: Heinle\&Heinle.

2. Fisher D., Frey N., and Rothenberg C. /Content-Area Conversations/ Chapter 1, p.3. 2 - Oct, 2008

3. Etacude Membership_http://bit.ly/edumember

4. Mc Cafferty, S. G., Jacobs, G. M. \& Dasilva Iddings, A. C. /Cooperative Learning and Second Language Teaching/ New York: Cambridge University Press, 2006. Print

5. Tanner.R. \& Green. C. (1998) /Tasks for teacher education. UK.Addisson Wesley Longman.LTD. 